\title{
産官学少人数穊談会 概要
}

\section{テーマ「データヘルス改革ービッグデータが生み出す変革についてー」}

日 時 2018年 1 月19日 (金) $18: 00 \sim 20: 00$

場 所 医療科学研究所 会議室

プログラム

挨拶 医療科学研究所理事長江利川 毅

座長挨拶 帝京平成大学薬学部教授/

医療科学研究所理事（産官学懇談会事業等委員会委員長）白神誠

講演 厚生労働省データヘルス改革推進本部事務局長代行／

大臣官房審議官（医療介護連携担当）伊原 和人

自由討議

参 加 者 合計15名

政府関係 4 名 厚生労働省/独立行政法人 医薬品医療機器総合機構

医薬品産業関係６名 エーザイ（株）／武田薬品工業（株）／ファイザー（株）／日本 製薬工業協会

学識者 2 名 帝京平成大学/慶應義塾大学大学院

医療科学研究所役員・関係者 3 名

※文中の事実関係は，原則として開催当時のものとなっています。

\section{＜産官学少人数懇談会 開催趣旨 $>$}

産官学少人数穊談会は, 医療分野の課題から時 宜にかなったテーマを定め, 産業界・政府・学界 (産官学) のキーパーソンが一堂に会し, 問題の 把握と解決について議論を行うことを目的として います。懇談会では, テーマに関する講演が行わ れ，その後，自由討議が行われます。

『医療と社会』では,「産官学少人数懇談会概要」 として, 講演と自由討議の様子を紹介します。産
官学少人数懇談会では, 自由討議において, 率直 に情報・意見の交換を行うことを基本としていま すが, 極めて重要でありながらも, 新規性が高く, 評価が流動的である内容を扱うことから，『医療 と社会』への掲載にあたっては発言者名は匿名と することとしました。

また, 産官学少人数㖃談会の議論から, 特に重 要なテーマを採り上げて,「産官学シンポジウム」 を開催しています。その内容も『医療と社会』に 講演録として揭載しています。 


\section{講演「データヘルス改革について」 \\ 厚生労働省データヘルス改革推進本部事務局長代行 \\ 大臣官房審議官（医療介護連携担当）伊原和人}

伊原 医療保険を担当するのは15年ぶりです が,「ビッグデータ」や「データヘルス」という 言葉を聞かない日はありません。日々，データの 持つ威力を見せつけられています。すごい時代が 来たなと思っています。加えて，AIをはじめ日 進月歩の技術革新を背景に期待感が高まっていま す。と同時に，どこまで実用できるのかという懐 疑の声もあります。例えば，私が入省した 30 年以 上前から，ICカードに医療情報を入れて，それを 持って医療機関を受診することで, 検査の無駄が 省けるだろうと言われていました。現在では，技 術の進展とともに，ICカードに医療情報を入れる のではなく, サーバーに登載された情報を見ると いう仕組みに変わりました。局地的には，こうし たネットワークが構築された地域もありますが, 全国的にみるとなかなかうまくいっていないとこ ろも多いです。寄せられる期待は高いのですが, 実際にどれくらいのことができるのかという点で 分からない，疑問があるというのが現状かもしれ ません。今日は, 我々が各種の医療のビッグデー 夕を使って，どのような改革をしょうと思ってい るのか，具体的には，2020年に向けて実現を目指 している7つのサービスについてお話しします。

データヘルスを考える際に, 利用対象となる データには 2 種類あります。一つはカルテの情報。 最近では電子カルテも増えてきていますが，いま なお紙も多いです。これに対して，レセプトの情 報があります。これは比較的早く電子化されまし た。したがって, データヘルスというと, 初期の 議論は, 専ら電子化されたレセプト情報をどう保 健事業などに活かすか, というものでした。

およそ15年前，私は保険局に在籍していました が, そのときは, 小泉純一郎総理（2001～2006年）
の医療制度改革に携わりました。「三方一両損」 ということで，患者負担を 3 割にする，協会けん ぽの保険料率を上げる, 診療報酬も大幅なマイナ ス改定を行うといった大変な改革でした。その当 時まとめたのが医療制度改革試案（2001年 9 月） ですが，その中でデータヘルスがどのように位置 付けられていたのかを調べてきました。まずレセ プト電算処理については,「大病院を中心にレセ プト電算処理を進めましょう」と言っていました。 具体的な取り組みのひとつが, 傷病名マスターの 標準化です。また，「インターネットを活用して オンライン請求を行うことについて検討を開始し ましょう」という段階でした。今日，レセプトの 電算化は $100 \%$ です。病院はほとんどオンライン で結ばれています。開業医の場合, オンラインで はないですが, CD-ROMで送って下さるので, 電子化自体はほぼ100\%です。特定健診はすでに $100 \%$ を達成しています。今から考えると，15年 前は, ちょうどデータヘルスの取り組みを始めま しょうという時期でした。

この15年でデータヘルスの環境は一変しまし た。電子化されたデータをどう利活用するのかと いう検討を塩崎恭久大臣（2014～2017年）のと きに集中的に行いました。各種の懇談会・検討会 を作り, ICT利活用やビッグデータの活用とあわ せて，その担い手として，審査支払機関の改革を 行うという観点から，検討を進めてきました。去 年の 7 月にデータヘルス改革推進計画をまとめま した。そのウイングは, がんゲノムや $\mathrm{AI}$ 活用 にまで広がり（資料 1)，2020年に 7 つのサービ スを実現しょうという意欲的なものとなりました (表1)。 


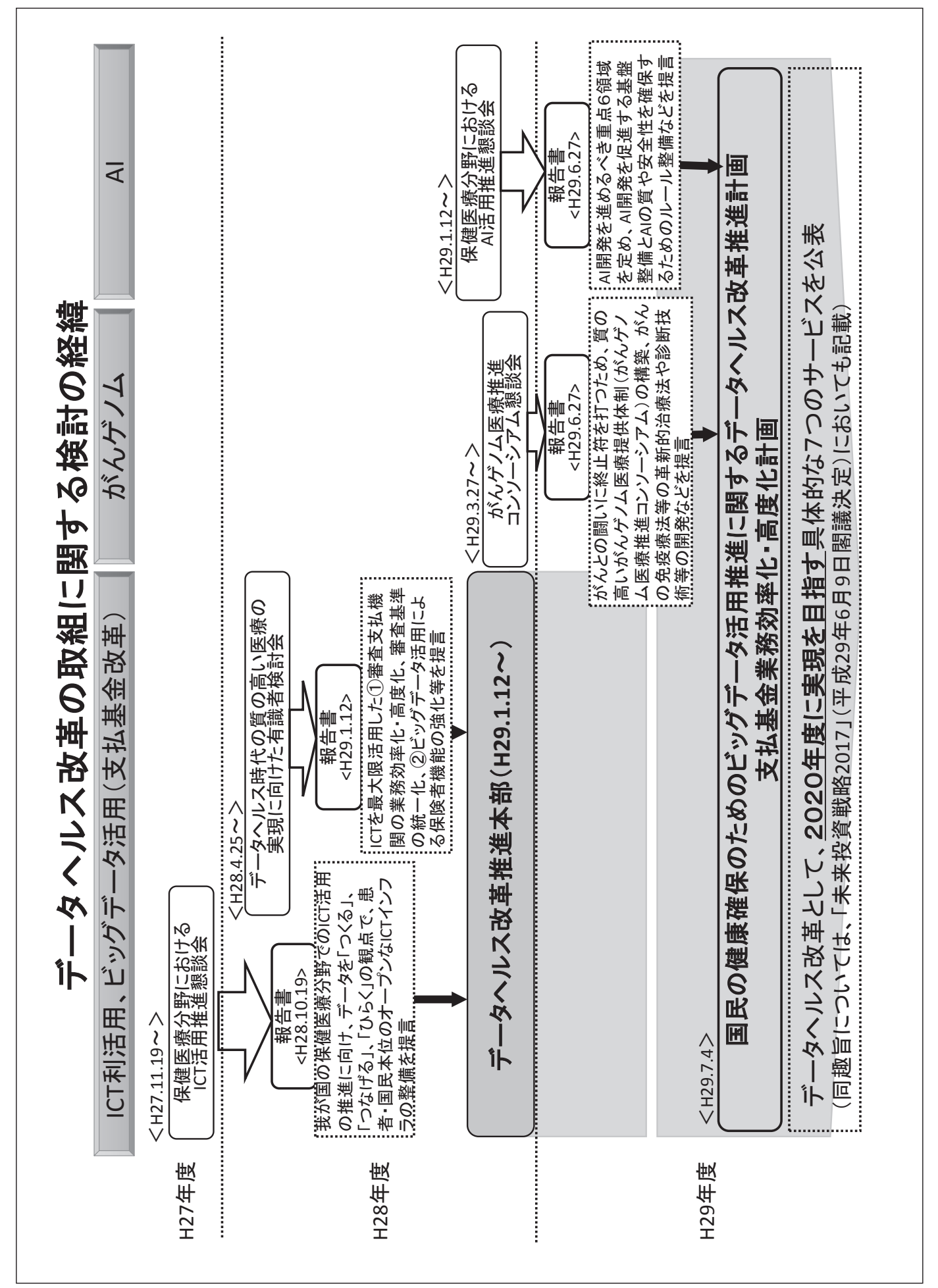




\section{表 1 データヘルス改革により提供をめざす7つのサービス}

I 全国的なネットワーク構築による医療・介護現場での健康・医療・介護の最適提供

(1) 全国的な保健医療ネットワークを整備し，医療関係者等が円滑に患者情報を共有できる サービス

(2) 医療的ケア児（者）等の救急時や予想外の災害，事故に遭遇した際に，医療関係者が， 迅速に必要な患者情報を共有できるサービス

II 国民の健康確保に向けた健康・医療・介護のビッグデータ連結・活用

(3) 健康に関するデー夕を集約・分析し，個人（PHR）や事業主（健康スコアリング）に健 康情報を提供するサービス

(4) 健康・医療・介護のビッグデータを個人単位で連結し，解析できるようにするサービス

III 科学的介護の実現

(5) 介護の科学的分析のためのデー夕を収集し，最適サービスを提供（世界に例のないデー タベース構築)

IV 最先端技術の導入

（6) がんゲノム情報の収集，医療関係者等が利活用できるサービス

(7) AI開発基盤に必要なデー夕を収集し，研究者や民間等が利活用できるサービス

ビッグデータを活用したサービスを実現するに は，基盤となるインフラが必要です。その一つと して，被保険者番号の個人単位化を予定していま す。マイナンバーを使えばいいのではないかと思 われる方も抽れると思います。しかし，マイナ ンバーは税・行政分野で用いることが原則であり, 利用範囲が厳しく制限されています。また，マイ ナンバーを不正に書き取るなどの行為は藅則が科 せられるなど，医療現場にとって，その取扱いが 難しい面があり，これを直接，利用することには なっていません。そのような中で, 現在検討中の オンラインによる被保険者資格の確認システムの 導入にあわせて「被保険者番号」を活用してはど うかという議論が進められています。

問題は, 現在の保険証の番号は世帯単位となっ ており，家族で番号が同一であることです。番号 が同じだと個人単位でデー夕をつなげ，管理する ことはできないので，これを個人単位に切り替え る必要があります。

もう一つの課題は, 会社が変わると保険者が変
わり, 被保険者番号も変わることです。そこで, 保険を移っても，被保険者番号の履歴を管理し， 生涯を通じて把握できる仕組みを，支払基金と国 保中央会が共同で作ることを検討しています。こ うした仕組みを導入することによって，医療機関 と審査支払機関との間でオンラインによって被保 険者の資格確認ができるようになります。患者さ んが医療機関を受診する場合, 保険が変わると, 新しい保険証を提示しなければなりません。しか し，新保険証の発行が遅れた場合など，古い保険 証を出してしまう方がいます。古い被保険者番号 を使って医療機関が診療報酬を請求すると, 審査 支払機関からリジェクトされます。こうした資格 過誤は保険者や医療機関の事務負担となってお り，推計では年間80億円にもなると見达まれてい ます。オンライン資格確認の仕組みができるとこ うした負担は大きく軽減されると考えています。

現在は，医療機関で保険証を提示して，空口で 資格確認をしています。新たな仕組みではマイナ ンバーカードをカードリーダーに通すと，初診の 
場合，審査支払機関につながって，そこから氏名， 性別，生年月日，保険者名，被保険者番号，負担 割合, 資格取得喪失日が送られてきます。医療機 関側では，これで本人確認ができますし，これら のデー夕をそのまま使えば，新たに入力作業を要 することなくカルテも作れます。

2020年度の実現をめざして作業を進めています が, 当初は, 外来受診が多い病院を中心に導入が 進むのではないかと期待しています。

オンラインによる資格確認とあわせて特定健診 のデータをマイナポータルによって国民一人ひと りが見ることができるようにするプロジェクトを 進めています。

特定健診部分のデー夕は全て保険者から支払基 金に送られています。これをマイナポータルで見 られるようにする仕組みです。特定健診のデー夕 については，患者さんだけでなく医療機関にも ニーズがあります。マイナポータルはスマホでも 閲覧可能ですから，受診時に，「これまで血糖值 はどうでしたか」と訊かれたらスマホを見せれば よい，ということになります。

以上が, データヘルスのインフラとなる部分です。 次に, 医療機関相互で保健医療記録を共有する というプロジェクトについてご説明します。医療 機関で生成される情報としては，レセプト情報以 外にカルテ情報があります。以前は紙でした。最 近は電子カルテが普及していて, 電子化されてい ます。さらにMRI，CTなどの画像も電子化され ています。こうしたデータを医療機関同士で共有 できると, 重複検査が省けるほか, 診断・治療に 役立ちます。

現在，すでに全国250を超える地域でこうした 医療機関同士の情報を相互に見ることができる仕 組みが構築されています。長崎, 滋賀, 岡山など, 結構，機能しているところもあります。残念なが ら仕組みがあってもあまり使われていないところ もあります。現在, 国で検討を進めているのは, こうした圈域単位で運用されているネットワーク
を全国でつないで，どこへ行っても見られるよう にしょうという構想です。こうした医療情報を共 有する構想自体は私が役所に入った頃，つまり 30 年以上前からありました。以前の構想では医療情 報を医療機関でICチップに入力して本人が持ち 歩く，というものでしたが，現在は電子カルテに 書き込まれ，サーバーに載せられたデー夕を他の 医療機関でも見られるようにしようという形です。

実現に向けた課題はランニングコストです。仮 に最初のシステム開発を国が応援したとしても, その後の運営を維持してゆく必要があります。そ の際，セキュリティ対策をはじめ結構，お金がか かります。これを誰が負担するのか。システムを 利用するのは医療機関です。医療機関は, 患者さ んが別の医療機関で撮った画像を見ることができ れば便利でしょう。では，どの程度の負担であれ ば利用していただけるでしょうか。また，実施主 体をどうするかといった課題もあります。

コストをどこまで下げられるのかも大切なポイ ントです。その選択肢の一つがクラウドです。オ ンプレミスと比べてコストが大きく下がります。

こうした課題について，今年の夏までに，一定 の結論を得られるよう議論を進めることとしてい ます。

世界的に見ると,イギリスやオーストラリアが， こうした医療情報の共有を行っています。これら の国の医療は，税方式であり，医療提供体制も公 的部門のウェートが大きく, 統一的な仕組みを導 入しやすい状況にあります。他方，日本は多くの 医療機関が民間ですから，そういうわけにはいき ません。それぞれバラバラに情報システムを導入 しています。また，オーストラリアでは，導入し たのはいいけれど, 最初はあまり利用されなかっ た。あまり使われず，無駄遣いじゃないかとの批 判が高まり，コストを下げる努力とともに使い勝 手も工夫して何とか継続しています。こうした先 例も踏まえながら，日本ではどうしたらよいかを よく考えなくてはならないと思っています。 
類似の仕組みとして，日本で最近登場したのが MID-NETです。医療機関のデータを吸い上げて, 利用しようというところに共通性があります。こ のデータベースのメリットが想定されるのは製薬 業界や研究者ですが，どこまで広く利用されるよ うになるか注目しています。

次は, レセプトデータを使って, 保険者ごとに 医療費の状況や加入者の健康状態などについて見 える化（スコアリング）して，評価表を送付しょ うというプロジェクトについてです。

今, 国ではレセプトデータを基とするデータ ベース, いわゆるナショナルデータベース（NDB） を持っています。全国民の8年分のレセプトデー 夕を追うことができます。これらのデータは匿名 化されています。これを使って，今年から，健保 組合ごとに, 例えば職員の肥満の割合が他の保険 者と比べて多いのか少ないのか, 脂質がどうか, 血圧はどうかなど，とレーダーチャートの形にし て，それぞれの保険者に通知することを予定して います。医療費についても年齢等を調整した上で, 他の保険者と比較できるようにお示ししたいと 思っています。さらに, 2020年度からは, 保険者 単位ではなく，個々の事業者ごとに同様の評価表 を示すことができるようなシステムを稼働予定と しています。経営者の方々に自社の従業員の健康 問題を見える化し, 健康経営に努めていただきた いと思っています。

ちょうど本年 4 月から，保険者ごとに新たな医 療費適正化計画を進めていただくことになってい ます。各健保組合は高齢者医療の拠出金を負担い ただいていますが，この負担額が組合ごとの医療 費適正化の取り組み次第で10\%増えたり, 減った りする仕組みを導入します。保険者インセンティ ブと呼んでいますが, これからは保険者の取り組 みがより一層, 保険財政にも影響してくることに なります。ぜひ，健保組合の関係者の皆さまにも このスコアリングの結果に関心を持っていただけ ればと思っています。
次がデータヘルス分析のプロジェクトです。現 在, 国はNDBや介護保険のデータベースを持っ ています。これらを個人単位で連結させて, 時系 列でどのような医療を受けているのか, どんな介 護サービスを利用しているのかなどをトータルに 分析できるようにしていこうとしています。さき ほど平成14（2002）年の医療制度改革の話をしま したが，その頃のデータ分析というと，日本全体 や都道府県別の医療費は把握していましたが，そ れ以外の詳細な分析となると, 元データが入力さ れていないためにできなかったり, 入力されてい ても出力に月単位で時間がかかり必要なときには 間に合わないというような状況でした。時がたち， 数年前に難病の医療費助成法案を担当したことが ありますが，その頃になると，レセプトデータが 電子化されているので分析自体は可能でした。発 注すると 1 力月程度, 時間はかかりましたが, パー キンソン病で医療を受けた患者さんの人数や医療 保険上の所得階層別の人数，1 カ月あたりの医療 費などは出てくるようになっていました。さらに 今では, システムの機能もアップしていて，ある 程度の分析なら, 数時間あれば結果が分かるまで に早くなりました。データは, 平成21（2009）年 度以降の 8 年分, 皆保険ですから約130億のレコー ドがあります。これはものすごいデー夕量です。

今, 行政以外の第三者のうち利用できるのは研 究者までです。これをどこまで開放するかが課題 です。例えば, ある病気の患者さんが何人いるか, 一人あたり医療費は月単位でどれくらいか, どの ような薬を使ったかも出てきます。製薬企業の 方々も欲しいと思うのではないかと思います。た だ，全て法律に基づいて医療保険や介護保険の適 正な運用という公益目的で集めているデー夕なの で，その提供に当たっては目的に合った形でなく てはならないと思います。来年法案を出す予定で すが，その際，公益目的で集めたデー夕をどの範 囲で，どのような条件で民間企業を含めた第三者 に使っていただけるかを考える必要があると思っ 
ています。

産業医大の松田晋哉先生による分析の一例です (資料 2 )。現段階では，全国ベースでは医療保険 データと介護デー夕は連結されていません。とこ ろが市町村レベルだと，国保と介護保険は同一主 体で運営されているので，連結ができます。この 資料 2 はある県のデータです。ある月に脳梗塞で 急性期病院に入院した人が, 入院する半年前から どのような医療サービスを受けていたか，入院し た後の半年間にどのような医療サービスを受けて いたかを見たものです。また，同じ人が入院する 前にどのような介護サービスを使っていたか，入 院した後にどのような介護サービスを使っていた かも示されています。

意外なことに, 脳梗塞を発症し入院する前に, 半数の人が既に介護サービスを利用しています。 つまり要介護になっている人の脳梗塞の発生率が 高いということです。それから, 認知症の人の脳 梗塞発症率が高い。さらに入院後 $30 \%$ 以上の人が 肺炎を発症しているので，入院中の管理が大事だ ということが分かります。デー夕を連結すること で，このように医療と介護の両面からあわせて検 討することができます。

次は乳幼児期・学童期における健康情報に関す るプロジェクトです。私が子どもの頃は，乳幼児 健診や予防接種は保健所や地域の集会所に集めら れて，集団的に実施されていました。今ではその 多くが個々の医療機関で実施されています。これ らのデー夕は市役所に集められ, 誰がいつ何の予 防接種をしたか, 健診を受けたかどうか, 結果は どうだったかが蓄積されています。学童期になる と, 学校保健安全法に基づいて毎年健診が行われ ています。問題点の一つは, 乳幼児健診のデータ の取り方が標準化されておらず，自治体ごとにバ ラバラであることです。それから，健診の結果は 母子手帳には書かれているのですが，電子化され ていない場合も多く，母子手帳がないと他の機関 が見ることができません。他方，学校健診は検査
内容など全国で統一されていますが，紙での保存 が一般的で，電子化されていません。そこで，乳 幼児健診は標準化を進めよう, 学校健診は電子化 をしよう，そして，これらをつなぎ，就学前から 就学後へと健康情報がつながるようにしようとい う議論をスタートさせようとしています。日本ほ ど乳幼児期の健康データをしっかり採っている国 はありません。学齢期までをも含めたデータベー スができあがれば，世界に誇れるものになるので はないかと思います。

介護分野でも,「科学的介護」という切り口で データベースの構築を進めています。介護保険で は, 介護保険総合データベースとして要介護認定 情報や介護レセプト情報を保有しています。さら に,リハビリのデータもデータベース化していま す。これらに加えて，どのような介護を受けたの か，それによって，提供後の状態がどう変わった のかなど，介護サービスが自立支援などにどうい う効果があるのかについて科学的に分析するため のデータベースを構築することとしています。現 在, 検討会で収集するデータの内容などについて 検討中です。

次が，がんゲノムの分野です。肺がんの治療薬 イレッサが有名ですが, 分子標的薬の場合, 遺伝 子変異とマッチするかどうかが鍵を握ります。遺 伝子変異の情報を知り, できるだけ効果が高いと 思われる患者さんに，薬を投与する時代です。そ こで，まずゲノム情報を集積しようということで, 全国で10施設くらいをがんゲノム医療中核拠点病 院に指定して，そこでがんを再発した人などを中 心に遺伝子情報を登録してもらい，それをがん研 究センターのがんゲノム情報管理センターに集約 します。これを企業や大学で研究に活用できるよ うにしましょうというプロジェクトを進めています。

あわせて医療保険上の課題として, 現在, 先進 医療となっている遺伝子パネル検査の保険適用の 問題があります。もし仮にこうした検査が保険適 用されるとした場合，対象者をどうするかという 


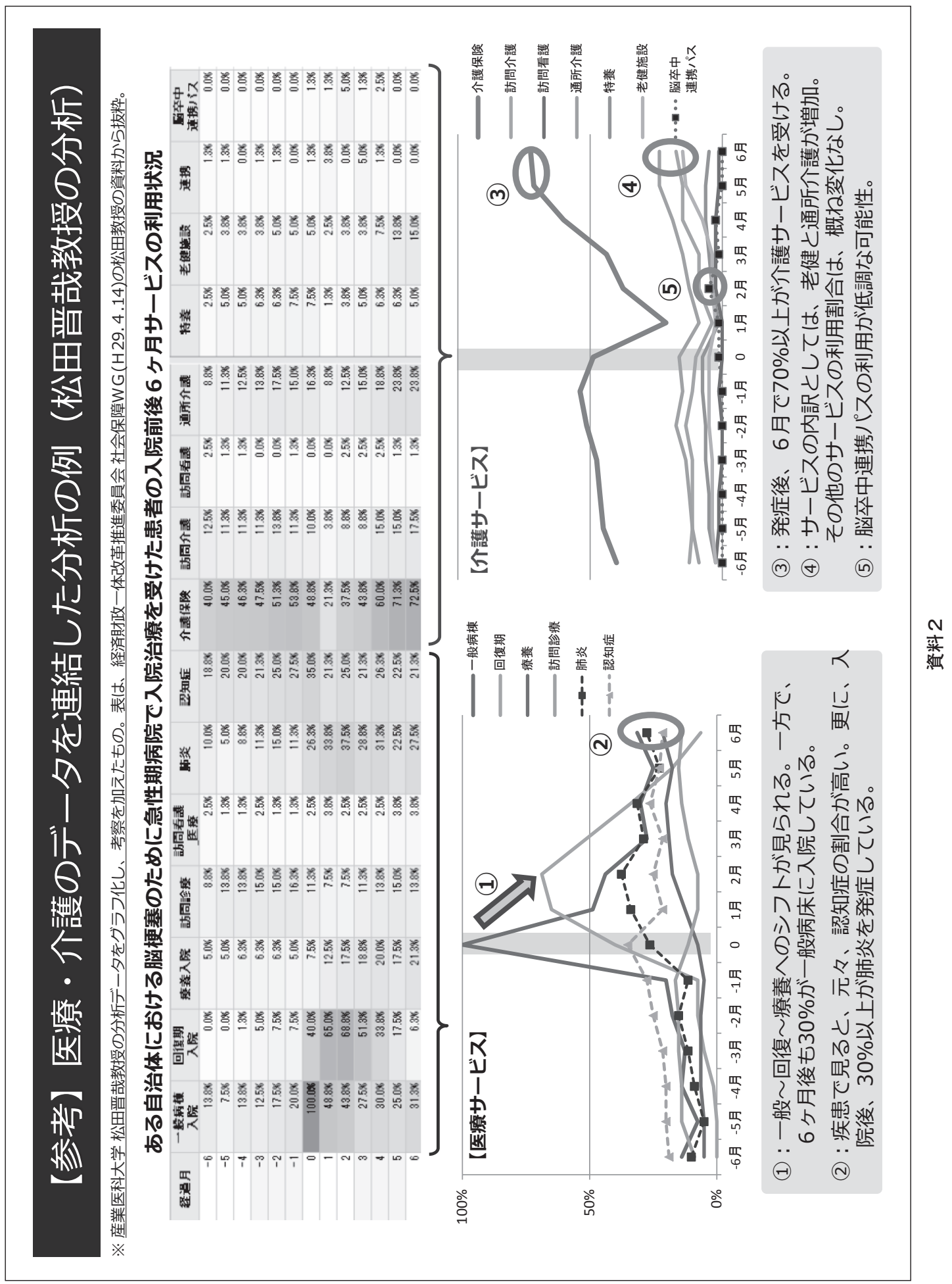


問題があります。 1 年間に新たにがんと診断され る患者数は 100 万人を超えるとされています。現 段階で費用対効果を考えた場合，おそらく，全員 に適用するわけにはいかないでしょう。ある程度 ステージが進んだ段階という線を考えるのでしょ うが，患者の立場からしたら，がんになったら自 分の遺伝子がどうなっているのか, 将来の抗がん 剂の選択肢はどうなのかを知りたいというニーズ もあるでしょう。保険適用をどうするのかは悩ま しい問題です。

最後のプロジェクトは, AIです。AIは 6 領域 (画 像診断支援, 医薬品開発, 手術支援, ゲノム医療, 診断・治療支援，介護・認知症）で開発を進める こととしています。AIの活用例として，分かり やすいのはカプセル型内視鏡です。通常, 胃の内 視鏡検査で30分〜 1 時間，大腸だと検査までの準 備だけで数時間もかかります。これがカプセル式 だと時間的にも，身体への侵襲という面でも負担 が軽減されます。カプセルが体内で撮った画像を AIが解析すれば, 医師の診断の負担も大きく軽 減できます。

$\mathrm{AI}$ 実用化に当たっては, 画像をできるだけ 多く集めるだけでなく，それらが正しく診断され たものである必要があります。そのためには，病 理医がしっかりと診断したデータであることが重 要です。病理医がいない病院のデータであれば拠 点病院に集めて, きちんと診断してもらった上で, データベースに登録してもらうことが大事です。
最後に，こうしたヘルスデータを予防・健康づ くりの観点から実際に活用している事例を紹介し ます。

協会けんぽでは, 先ほどご紹介したスコアリン グのような「ヘルスケア通信簿」という成績表を 事業主に送っています。例えば, 御社の医療費は 同業他社の中で2999位中180位ですといったもの です。

また, ジェネリック医薬品軽減額の通知も行っ ています。あなたが今飲んでいるブランド薬を ジェネリックに替えると, 薬剤費負担がいくら減 りますという通知をしています。

このジェネリック医薬品軽減額通知は, 平成 21 （2009）年からスタートしています。興味深いこ とですが，送付された人のうち 4 人に 1 人がジェ ネリックに切り替えています。平成28（2016）年 度では610万件送付し，うち154万人が切り替えま した。郵送費などのコストが6.1億円に対し，財 政効果は270億円です。15年前に保険局に在籍し ていたときは，とてもこんなことはできませんで した。その後レセプトデータが電子化されて, 個 人単位でどの薬を飲んでいるかが把握されるよう になり，できるようになったのです。

このようにビッグデータには色々な可能性があ ります。今後, さらに利活用が進んでいくと思い ますし, 我々としても最大限の努力を払っていき たいと思っています。ご清聴どうもありがとうご ざいました。 